\title{
THE PHOTOVOLTAIC ELECTRIFICATION IN ISOLATED COMMUNITIES OF CARDOSO ISLAND STATE PARK - SP ${ }^{1}$
}

\author{
Luciene M. Baschiera ${ }^{2 *}$, Maria A. Fagnani ${ }^{3}$
}

${ }^{2 *}$ Corresponding author: Universidade Estadual de Campinas, UNICAMP/ Campinas - SP, Brasil.

E-mail: luciene.baschiera@gmail.com

\section{KEYWORDS}

solar energy, energy demand, implantation process.

\begin{abstract}
This study concerns a research conducted in 2014, in isolated communities of Cambriú and Foles belonging to the Cardoso Island State Park-SP, in order to establish a link between electrification through isolated photovoltaic systems type SIGIFI 30 (30 $\mathrm{kWh} /$ month) with the existing demands, interactions and changes in traditional communities studied. The energy in this case is presented as a structure component to these demands regarding to the labor, agriculture, fishing, health, education, comfort of buildings and income generation. The objective was to conduct an analysis of the implementation of photovoltaic electrification process, and to establish a relationship with the surveyed communities. The results demonstrated that electrification provided benefits to the residents of the communities, but it only achieves real success if linked to other public policy instruments such as health, education and transportation that considered the diversities and peculiarities of these populations with regard to the strong isolation to which they belong. It was also noted that the training or technical assistance provided was not characterized as causing problems for residents, that in the majority did not present significant complaints to the management and the operation of the installed systems.
\end{abstract}

\section{INTRODUCTION}

The issue of access to energy and electrification has been addressed since the last decade as one of the fundamental themes for world development, and according to Modi et al. (2005) and United Nations (2015), it plays a key role in achieving the seven Millennium Development Goals (MDGs). The goals proposed to the member countries are to promote the eradication of poverty, hunger, diseases, exclusion and lack of housing infrastructure at the same time as promoting gender equality, education, health, environment and sustainability. The energy destined to rural applications can favor the development of the countryside, as well as its lack can impact socio-economic activities (Mishra \& Behera, 2016), cultural and social service provision as well as propitiate rural exodus (Gicquel \& Gicquel, 2013).

Most of these actions have been carried out by government policies and organizations with low private sector participation. According to Williams et al. (2015), the lack of capital from public sources and donor organizations makes it difficult to reach the goals of access.
In the Brazilian scenario, according to MME (2015) these actions have mainly occurred due to government programs such as the Light for All Program (LAP), which provided electrification to 3.2 million families in countryside/rural area of Brazil by the end of 2015 .

With regard to electric power generation by source in Brazil, according to EPE (2016) in the base year of 2015, it was represented by: Hydroelectric (61.9\%), Natural Gas (13.7\%), Biomass (8.2\%), Petroleum Derivatives $(4.4 \%)$, Wind $(3.7 \%)$, Coal $(3.3 \%)$, Nuclear $(2.5 \%)$ and Other Sources $(2.4 \%)$, totaling 581,486 GWh in connected systems. Most of these systems are far from the isolated communities, making it impossible to extend the conventional network favoring the use of "other sources" such as solar, wind, tide, hydro and biomass, for micro and mini generation. According to Sánchez et al. (2015) these technologies have been shown to be a more convenient and economical option than the use of diesel for electricity generation.

According to SERPA (2001) photovoltaic electrification is the one that offers the best results in the electrification of isolated and dispersed communities, especially those in remote areas, offering a better cost/benefit ratio.

\footnotetext{
${ }^{1}$ Extracted from the master's dissertation of the first author

${ }^{3}$ Universidade Estadual de Campinas, UNICAMP/ Campinas - SP, Brasil.

Received in: 5-23-2016

Accepted in: 6-4-2018
} 
According to a study by the United Nations Food and Agriculture Organization (FAO) in rural applications (Campen et al., 2000), photovoltaic electricity can bring numerous benefits to communities and being essential for sustainable agriculture and rural development. The literature has demonstrated the utilization potential in agriculture in several applications (Valer \& Zilles, 2011) such as: lighting, irrigation (Chandel et al., 2015), cultivation in greenhouses (Hassaniena et al., 2016), processing and drying of grains, poultry, fish farming, with great interest for pumping (Valer et al., 2013), family farming (Dell'Anna \& Menconi, 2016) and rural community applications (Mendonça et al., 2006).

A particular case concerns to the isolated communities belonging to the preservation areas, such as the Cardoso Island State Park (PEIC), located on the south coast of São Paulo. In this scenario the electrification processes are more complex, because besides the geographic isolation these places are governed by restrictive laws that impose difficulties of implantation.

The electrification of rural residences in the Cardoso Island State Park was initiated in 1997 (Zilles et al., 2000) by the commercial program, called Ecowatt of the Energy Company of the State of São Paulo (CESP), but in 2001 it was registered bankruptcy of this project (Serpa \& Zilles, 2002). The current systems were installed by the Elektro concessionaire through the Light for All program in the year 2008 (SIGFI ${ }^{4}$ 13) and updated in 2013 for SIGFI 30. The rate practiced on the date of the survey was US \$ 12.5 (R \$ 30.00 - of the official commercial dollar in Oct. 2015) charged by the concessionaire every 3 months.

In this way, the objective was to carry out an analysis of the process of photovoltaic electrification ${ }^{5}$ implanted in the isolated communities of Foles and Cambriú and establish a relationship with the demands of these communities. To this end, a field survey was carried out in which the status of the implanted systems, maintenance, unmet needs and improvement of the living conditions of the population served.

\section{MATERIAL AND METHODS}

\section{Study area}

For the development of this research, the communities of Foles (latitude $25^{\circ}$ 9.679'S and longitude $47^{\circ} 55.638^{\prime} \mathrm{W}$ ) and Cambriú (latitude $25^{\circ} 9.300^{\prime} \mathrm{S}$ and longitude $47^{\circ} 55.151^{\prime} \mathrm{W}$ ) belonging to the Cardoso Island State Park located on the south coast of the state of São Paulo (lat. $25^{\circ} 05^{\prime} \mathrm{S}-25^{\circ} 15^{\prime} \mathrm{S}$ and long $47^{\circ} 53^{\prime}-48^{\circ} 06^{\prime}$ W) were selected. This area has mountainous topography and a coastal plain bathed by the Atlantic Ocean in its southeast part, where the communities are located.

The climate of the Cardoso Island State Park is CFA (Köpen classification) type, with average annual temperatures varying from $20^{\circ} \mathrm{C}$ to $22^{\circ} \mathrm{C}$ and average rainfall from $2261 \mathrm{~mm}$ to $3000 \mathrm{~mm}$, with precipitation throughout the year (São Paulo, 2001).

In the region, the southeast wind predominates with $40.1 \%$ of average annual persistence and $18.4 \mathrm{~km} / \mathrm{h}$ of medium intensity ${ }^{6}$ (MME \& ICMBio, 2016).

The insolation in the municipality of Cananéia reaches a maximum score of $5.9 \mathrm{~h}$ in February and a minimum of $3.2 \mathrm{~h}$ in September, with a minimum solar radiation of $7.66 \mathrm{MJ} / \mathrm{m}^{2} /$ day (July) and monthly maximum values of $16.32 \mathrm{MJ} / \mathrm{m}^{2} /$ day (February), data that make possible the use of solar energy for electricity generation (IEE-USP, 1994).

Figure 1 presents a satellite image of Cardoso Island showing its geographical location and its surroundings. Figure 2 shows the geographical details of the Cambriú and Foles communities.

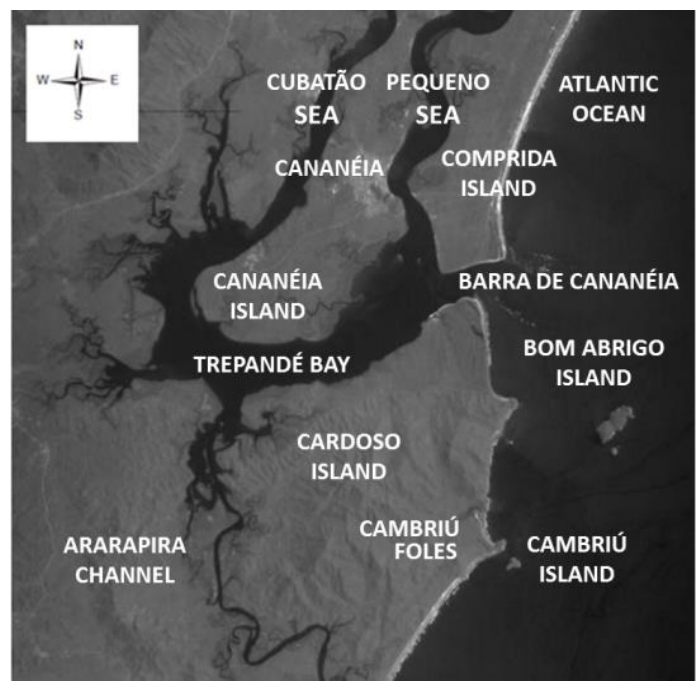

FIGURE 1. Satellite image showing the geographical location of Cardoso Island - PEIC-SP. Source: INPE - CEBERS2B ${ }^{7}$ Satellite.

${ }^{4}$ SIGIFI: Individual Power Generation System with Intermittent Supply

${ }^{5}$ Electrification process: Understand the relationship between communities and installed systems, as well as identify the operating conditions of systems and technical assistance.

${ }^{6}$ Compatible data for use with wind microgenerators.

${ }^{7}$ Figure composed of the image data of the CEBERS2B satellite accessed through the catalog of the Image Generation Division (DGI) of INPE, for the municipality of Cananéia, available at: http://www.dgi.inpe.br/CDSR/. Accessed on: April 09, 2016. 


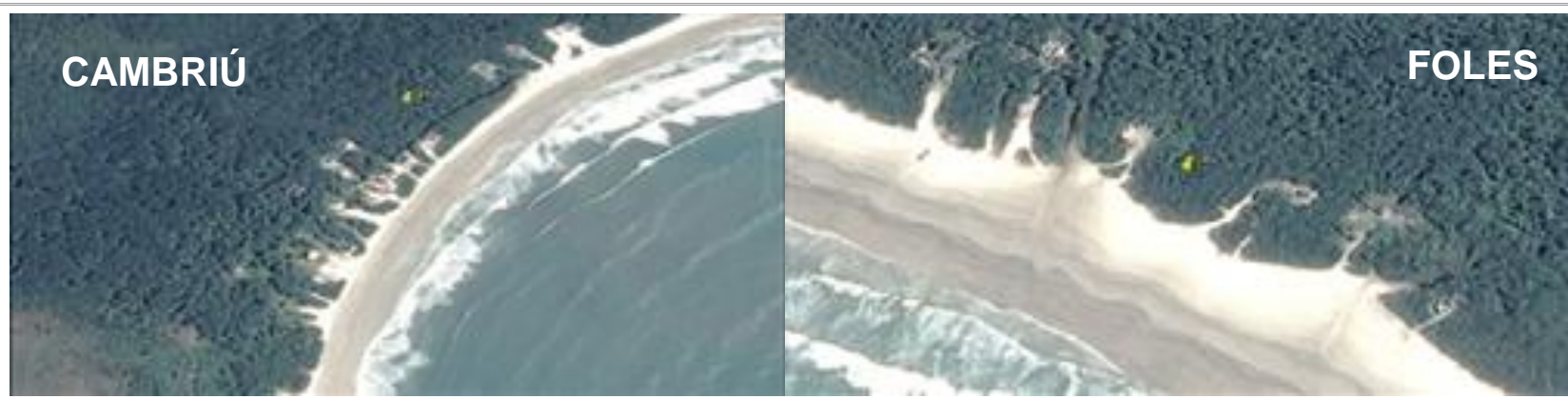

FIGURE 2. Geographical details of isolated communities Cambriú and Foles. Source: Google Earth (2013 database).

\section{Access to communities and geographic isolation}

The access to Foles and Cambriú is made only by boats in two possible routes, one through the open sea for approximately $18 \mathrm{~km}$, about $1 \mathrm{~h} 40 \mathrm{~min}$ from Cananéia by the estuary zone via Barra de Cananéia following the coast to the communities or through the channel from Cananéia to the community of Marujá by means of a private vessel or through the DERSA vessel through the Ararapira canal.

\section{Research Methodology}

In the scope of this research, semi-structured questionnaires were applied to the two communities, containing 100 questions divided in thematic groups. The questions were elaborated by a multidisciplinary team comprised of environmental, electrician and agronomic engineer in order to meet technical criteria of the installed systems, as well as socio cultural and economic criteria of the researched communities.

Quantitative data were collected regarding the socioeconomic and cultural characteristics of the communities, housing infrastructure conditions, access to services, as well as verifying the relationship of the interviewees with the energy through data of implantation, maintenance and use of the systems and demands yet existing. Due to the small number of inhabitants, a representative of each family was interviewed randomly, that is, 16 residents, 7 in Foles and 9 in Cambriú (100\% and $82 \%$ of the families present at the time of the survey, respectively). Thus, the total data of the total population (Foles and Cambriú) were considered in the statistical evaluations, using appropriate methods for small data sets, with frequency analysis and presentation in histograms for better visualization of the results.
In addition, documentary research was carried out at the Forest Foundation belonging to the Secretariat of Environment of the State of São Paulo and also with representatives of governmental programs that executed the installations of photovoltaic systems in the State Park of Cardoso Island (PEIC).

\section{Technical data of the system considered}

The system implemented by the concessionaire ${ }^{8}$ consisted of 3 photovoltaic panels with a nominal power of $135 \mathrm{Wp}\left(1000 \mathrm{~W} / \mathrm{m}^{2}\right.$ and $\left.25{ }^{\circ} \mathrm{C}\right)$, totaling $405 \mathrm{Wp}$, an electronic load controller, four stationary batteries of $12 \mathrm{~V} / 165 \mathrm{Ah}$ connected in parallel with capacity to deliver around $180 \mathrm{~W}$ for up to 10 hours (when fully charged) providing $720 \mathrm{~W}$ during the no-light period (full recharge takes 5 to 8.5 hours). For the conversion of direct current from alternating batteries is used an inverter (pure sine type) with $110 \mathrm{~V}$ output and a maximum power of $500 \mathrm{~W}$.

\section{RESULTS AND DISCUSSION}

The data collected by the research were organized, quantified and analyzed according to the thematic division quoted above and the most relevant results were compiled in Table 1, which presents a synopsis of the research carried out.

To better expose and analyze the results of Table 1, the discussion of the results will be divided into the following evaluation topics: socioeconomic and cultural aspects of communities, electrification in communities and operating conditions of the installed systems.

\footnotetext{
${ }^{8}$ Data from the standard platform of the SIGNIFI 30 system $(30 \mathrm{kWh} / \mathrm{month})$ according to information from the Elektro concessionaire, at the request of the authors.
} 
TABLE 1. Summary of performed research in Cambriú and Foles isolated communities, PEIC, 2014.

\begin{tabular}{|c|c|c|c|c|c|c|c|c|c|}
\hline \multirow{2}{*}{ Parameter } & \multicolumn{3}{|c|}{$\begin{array}{l}\text { Absolute frequency per } \\
\text { community }\end{array}$} & \multicolumn{3}{|c|}{$\begin{array}{l}\text { Relative frequency in total } \\
\text { communities }(\%)\end{array}$} & \multicolumn{3}{|c|}{$\begin{array}{c}\text { Cumulative relative frequency in } \\
\text { total communities (\%) }\end{array}$} \\
\hline & Foles & Cambriú & $\begin{array}{l}\text { Foles \& } \\
\text { Cambriú }\end{array}$ & Foles & Cambriú & $\begin{array}{r}\text { Foles \& } \\
\text { Cambriú }\end{array}$ & Foles & Cambriú & $\begin{array}{r}\text { Foles \& } \\
\text { Cambriú }\end{array}$ \\
\hline \multicolumn{10}{|l|}{ Population } \\
\hline No. of inhabitants & 10 & 32 & 42 & 23.81 & 76.19 & 100.00 & 23.81 & 76.19 & 100.00 \\
\hline No. of families & 7 & 11 & 18 & 38.89 & 61.11 & 100.00 & 38.89 & 61.11 & 100.00 \\
\hline Male & 7 & 17 & 24 & 16.67 & 40.48 & 57.14 & 16.67 & 40.48 & 57.14 \\
\hline female & 3 & 15 & 18 & 7.14 & 35.71 & 42.86 & 23.81 & 76.19 & 100.00 \\
\hline Children up to 4 years & 1 & 2 & 3 & 2.38 & 4.76 & 7.14 & 2.38 & 4.76 & 7.14 \\
\hline Children> 4 years & 0 & 0 & 0 & 0.00 & 0.00 & 0.00 & 2.38 & 4.76 & 7.14 \\
\hline Teenagers & 0 & 3 & 3 & 0.00 & 7.14 & 7.14 & 2.38 & 11.90 & 14.28 \\
\hline Adult & 8 & 21 & 29 & 19.05 & 50.00 & 69.05 & 21.43 & 61.90 & 83.33 \\
\hline Elderly & 1 & 6 & 7 & 2.38 & 14.29 & 16.67 & 23.81 & 76.19 & 100.00 \\
\hline Younger & 1 & 3 & 4 & 2.38 & 7.14 & 9.52 & 2.38 & 7.14 & 9.52 \\
\hline Active age & 8 & 23 & 31 & 19.05 & 54,76 & 73.81 & 19.05 & 54.76 & 73.81 \\
\hline Fertile age & 1 & 10 & 11 & 2,38 & 23.8 & 26.19 & 2.38 & 23.8 & 26.19 \\
\hline \multicolumn{10}{|l|}{ Fixing of housing } \\
\hline Island and continent & 0 & 14 & 14 & 0.00 & 33.33 & 33.33 & 0.00 & 33.33 & 33.33 \\
\hline Only island & 10 & 18 & 28 & 23.81 & 42.86 & 66.67 & 23.81 & 76.19 & 100.00 \\
\hline \multicolumn{10}{|l|}{ Degree of urban contact } \\
\hline Daily & 0 & 13 & 13 & 0.00 & 30.95 & 30.95 & 0.00 & 30.95 & 30.95 \\
\hline Weekly & 1 & 7 & 8 & 2.38 & 16.67 & 19.05 & 2.38 & 47.62 & 50.00 \\
\hline Biweekly & 5 & 8 & 13 & 11.90 & 19.05 & 30.95 & 14.28 & 66.67 & 80.95 \\
\hline Monthly & 3 & 2 & 5 & 7.14 & 4.76 & 11.90 & 21.42 & 71.43 & 92.85 \\
\hline Yearly & 1 & 2 & 3 & 2.38 & 4.76 & 7.14 & 23.81 & 76.19 & 100.00 \\
\hline \multicolumn{10}{|l|}{ Family Activities } \\
\hline Fishing & 6 & 11 & 17 & 33.33 & 61.11 & 94.44 & 33.33 & 61.11 & 94.44 \\
\hline Tourism & 2 & 5 & 7 & 11.11 & 27.28 & 38.89 & 11.11 & 27.28 & 38.89 \\
\hline Craft & 3 & 1 & 4 & 16.67 & 5.56 & 22.22 & 16.67 & 5.56 & 22.22 \\
\hline Retirement & 1 & 3 & 4 & 5.55 & 16.67 & 22.22 & 5.55 & 16.67 & 22.22 \\
\hline Student & 0 & 2 & 2 & 0.00 & 11.11 & 11.11 & 0.00 & 11.11 & 11.11 \\
\hline Other/Mainland & 0 & 2 & 2 & 0.00 & 11.11 & 11.11 & 0.00 & 11.11 & 11.11 \\
\hline \multicolumn{10}{|l|}{ System } \\
\hline SIGIFI (kW/month) & 30 & 30 & 30 & 38.89 & 61.11 & 100.00 & 38.89 & 61.11 & 100.00 \\
\hline \multicolumn{10}{|c|}{ Problems after installation } \\
\hline $\begin{array}{l}\text { Defects and } \\
\text { maintenance }\end{array}$ & 2 & 3 & 5 & 11.11 & 16.67 & 27.78 & 11.11 & 16.67 & 27.78 \\
\hline \multicolumn{10}{|l|}{ Field research } \\
\hline No of interviews & 7 & 9 & 16 & 38.89 & 50.00 & 88.89 & 38.89 & 50.00 & 88.89 \\
\hline
\end{tabular}

Statistical Population Analysis (Foles + Cambriú)

Age distribution of the total population: $\mathrm{N}=42 ; \mathrm{k}=5$ classes; Minimum = 2; Maximum = 85; Amplitude $=83$

1st Quartile =24; Mean =40.31; Median = 42; 3rd Quartile = 57; Mean std. dev. = 3.16; Std dev =20.47; Var = 419.10

Age distribution by gender - men: $\mathrm{N}=24 ; \mathrm{k}=5$ classes; Minimum = 2; Maximum $=75 ;$ Amplitude $=73$

1 st Quartile $=24.5 ;$ Mean $=40.42 ;$ Median $=44 ; 3$ rd Quartile $=57 ;$ Mean std. dev. $=4.14 ;$ Std. dev.$=20.30 ;$ Var $=412.16$

Age distribution by gender - women: $\mathrm{N}=18 ; \mathrm{k}=5$ classes; Minimum = 3; Maximum = 85; Amplitude $=82$

1 st Quartile =24; Mean =40.31; Median =38; 3rd Quartile = 59.25; Mean std. dev.=5.02; Std. Dev.=21.29, Var $=453.09$

Definitions considered:

Children aged 0 to 11 years, teenagers 12 to 18 years old (according to the Statute of the Child and Adolescent - BRAZIL, Law no. 8069 of July 13, 1990), adult 19 to 59 years, elderly 60 years or older (according to Statute of the Elderly - BRASIL, Law No. 10,741, of October 1, 2003), young people (up to 14 years old), active age (15 to 59 years), fertile age (women aged 15-49). 


\section{Assessment of socioeconomic and cultural aspects of the communities}

Cambriú and Foles are communities made up of traditional dwellers and caiçaras ${ }^{9}$, whose families are present in these places to at least three generations of fishermen-farmers.
From the analysis of the data, it was verified that the structure of the populations (Figure 3) consists of a majority of adults (69.05\%), few children (7.14\%) and teenagers $(7.14 \%)$ and some elderly $(16.67 \%)$ and a predominance of males $(57.14 \%)$ compared to females $(42.86 \%)$, with $26.12 \%$ of females of fertile age.

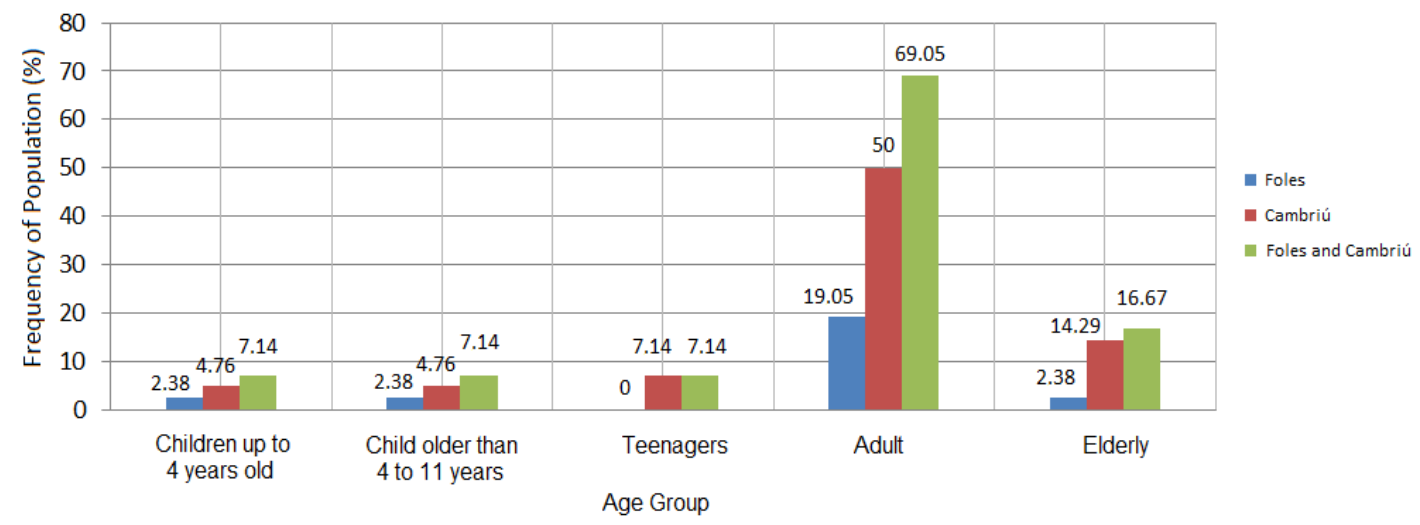

FIGURE 3. Age group of the population of Cambriú and Foles isolated communities - PEIC-SP. Source: research database, 2014.

Fishing is the main economic activity, practiced by $99.44 \%$ of families followed by tourism (38.89\%) and handicrafts $(22.22 \%)$. There are $22.22 \%$ of retirees, $11.11 \%$ of students and $11 \%$ in other activities. The population of active age is $73.81 \%$.

Prior to the creation of PEIC the population of these communities had as their main source of subsistence agriculture, they usually planted rice, manioc, watermelon, corn and beans, during this period the farmers made their own territorial ordinance and gave preference to open fields in greenery secondary education. In addition to planting vegetables on the beaches of Foles and Cambriú, they also had plantations in other points of the Island as in the beach of Lage.

However, due to the current legislative restrictions of the State Park, these populations are not allowed to carry out activities related to agriculture or livestock. It was verified that only a small part of the residences has some type of subsistence plantation, only a few units with small gardens.
Another finding revealed by the research concerns the establishment of communities. The absence of community services linked to education, health and jobs combined with geographic isolation has caused a displacement of the young population to other places.

It was verified that $66.67 \%$ of the inhabitants live only on the Island, while $33.33 \%$ live practically on the mainland, with little time remaining on the Island. This could also be verified by the high degree of daily urban contact $(30.95 \%)$ of a portion of this population corresponding to the portion of the population that studies or works in Cananéia. The weekly contact (19.05\%) and biweekly $(30.95 \%)$ correspond to the commercialization of fish and tourism, while monthly contact $(11.90 \%)$ and annual contact $(7.14 \%)$ relate to access to services on the continent.

Figure 4 graphically shows how these data are related to the population structure (gender and age) showing the frequency composition according to these groups, using the data from the contingency tables performed in the study.

\footnotetext{
${ }^{9}$ Historical and anthropological report for the identification of traditional families and indigenous villages present in the Cardoso Island State Park, Carvalho \& Schmitt (2012), we identified the presence of traditional residents in the Cardoso Island State Park, whose socio-cultural reproduction depends on the use of the natural resources of their territory and that this use has low environmental impact. Caiçaras are according to the authors coastal populations belonging to the Brazilian southeast.
} 
(A)

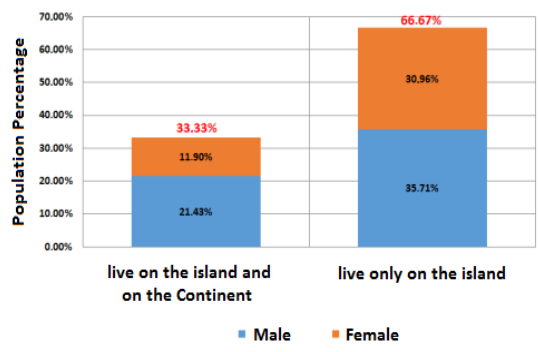

(C)

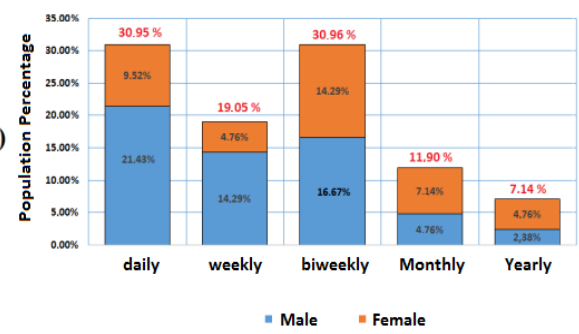

(B)

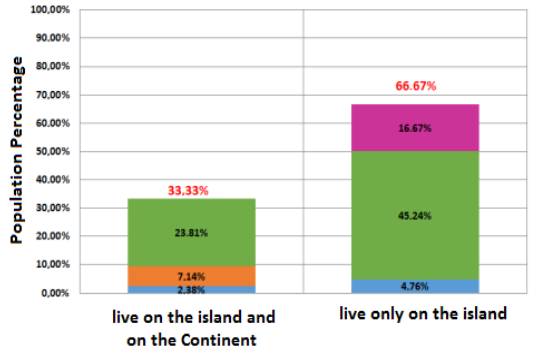

" Child $=$ Teenager $=$ Adult $=$ Elderly

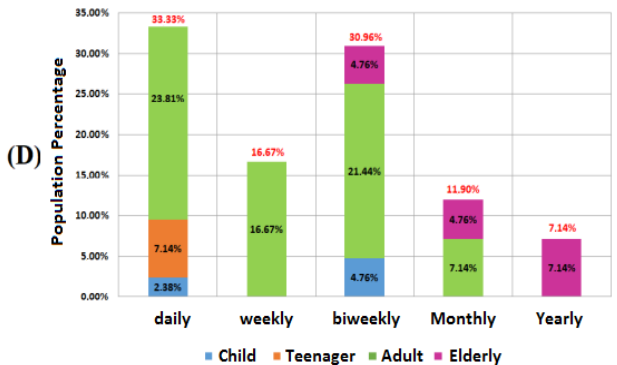

FIGURE 4. Contingency analysis. (A) Gender vs. fixation, (B) age group vs. fixation, (C) sex vs. urban contact and (D) age group vs. urban contact. Source: research database, 2014.

This situation represented by a small number of children, a predominant male population, few women of fertile age, lack of community services and basic education, combined with a greater supply of jobs on the continent in activities that are far from the tradition of communities, advocates a long-term scenario of the extinction of these communities, as has already occurred in other communities of the island such as Ipanema and Lage.

It was certified that despite the benefits obtained with the electrification process, those populations have other demands mainly due to factors of isolation, evasion, transportation, health, education and income generation, which have led to the understanding that only the electrification seen in isolation form does not constitute a resolution of the deeper issues, necessitating a link with other public policies that lead to the strengthening and sustainability of these populations over time.

\section{Evaluation of photovoltaic electricity in the communities}

Currently, 18 families living in Cambriú and Foles make daily use of the energy supplied by the photovoltaic systems, standardized and individual, installed in each residence.

The energy available for each residence is equivalent to $30 \mathrm{kWh} / \mathrm{month}$, with $500 \mathrm{~W}$ of power, and does not support any additional demand, which according to the design of the system comprises: three points of light and two sockets with prediction of use of television and one radio.

Figure 5 shows the scheme of the systems installed by the concessionaire in the communities.
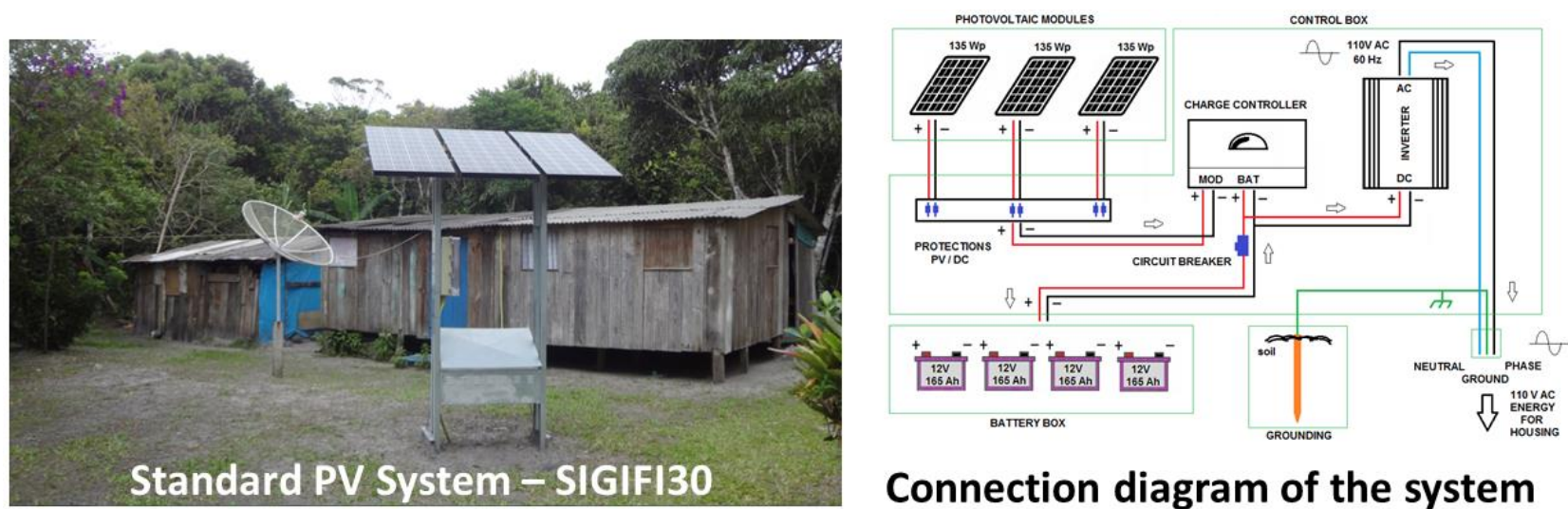

\section{Connection diagram of the system}

FIGURE 5. Photovoltaic systems installed in Cambriú and Foles isolated communities - PEIC-SP. Source: research database, 2014. 
The availability of energy offered by these systems is linked to the climatic conditions (sunshine, cloudiness and rainfall), as the solar panels carry the batteries of the system that effectively store the energy and convert it to the conventional network energy standard by the inverters $(110 \mathrm{~V}, 60 \mathrm{~Hz}$, sinusoidal). Therefore, depending on the stored load, only a fraction of the system capacity will be available for use by limiting the utilization. Thus the residents were instructed to save energy during periods of low insolation.

Concerning the capacity, $88.88 \%$ of Cambriú users and $100 \%$ of Foles users reported having received training from the concessionaire to use the system.

Regarding the problems that occurred after the implantation, $27.27 \%$ of the systems installed in Cambriú and $28.57 \%$ of Foles presented problems in some system component (inverters, batteries or load controllers). All maintenance was carried out by the concessionaire who manages the system and the waiting time ranged from three days to two months depending on the defect.

Another issue raised by the survey was related to the value of energy bills, residents reported having difficulties paying bills due mainly to factors linked to low income.

According to Serpa \& Zilles (2002), the lack of care during deployment, maintenance policy and the question of user training was responsible for failures of the previous electrification programs. Mendonça et al. (2006) mentions capacity and maintenance as fundamental to the subsistence of the system and that electrification still potentializes organizational processes mainly in education and health. Valer et al. (2013) points out that in pilot projects for the implementation of photovoltaic systems, after leaving the sponsoring institution or terminating financial resources, the community can not maintain the system and projects tend to be abandoned.
Another question addressed by Williams et al. (2015) is that the high risk factor in decentralized projects in low income areas with marginal returns and lack of clear and effective public policy imposes barriers to independent private sector participation (always acting within government programs), showing disinterest in the participation of this type of project. Thus projects with low resources, pilot deployments and lack of long-term goals tend to have problems of effectiveness, maintenance and sustainability.

In this way, it was verified that the management model adopted in the implementation of Photovoltaic systems in the Cambriú and Foles communities considered these issues, projecting a more sustainable system of electrification in the long term.

Regarding the economic transformations that occurred as a result of the electrification, $68.75 \%$ of the families declared that there was an improvement in income due to factors such as tourism, crafts making and networks in the nocturnal period. Similar impacts on isolated communities after electrification are described by Valer et al. (2014).

Regarding to social transformations in communities due to electrification, the survey found that $75 \%$ of respondents stated that access to energy provided an increase in free time during the night (for leisure activities, work or information), $81.25 \%$ of the families reported improvement in homes (lighting, appliances, power tools for maintenance), $56.2 \%$ had improved nighttime education, $93.75 \%$ had increased pride, self-esteem, and dignity, and $75 \%$ said they had improved the health. At the community level, $81.25 \%$ of the interviewees revealed that there was a greater participation and involvement of the communities, establishing a greater sociability among the residents. The graph of Figure 6 shows the distribution of the activities stimulated by the process of photovoltaic electrification.

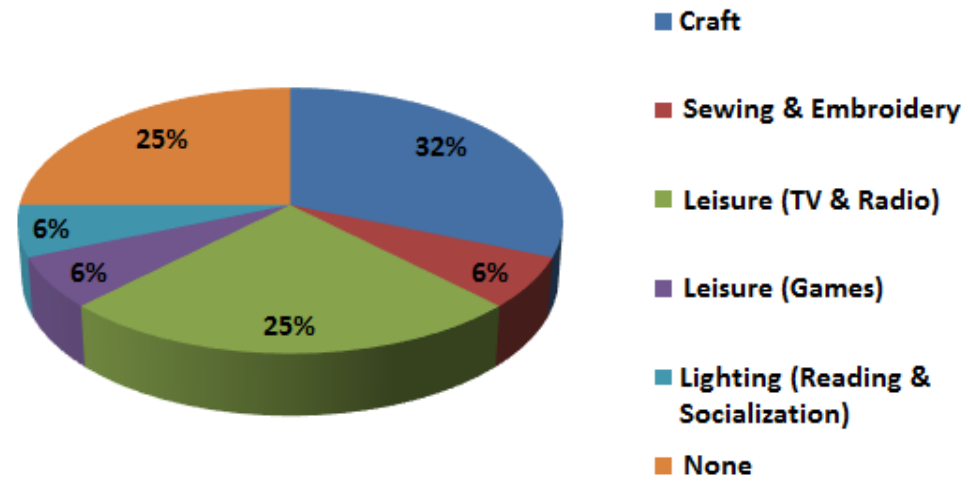

FIGURE 6. Stimulated activities in Cambriú and Foles isolated communities - PEIC-SP. Source: research database, 2014.

According to Mendonça (2006), electrification enhances organizational processes, especially in the areas of education and health. According to a study by FAO (Campen et al., 2000), the process of photovoltaic electrification can bring benefits in several areas in community terms. In this respect, the Foles and Cambriú electrification did not contemplate any community action, through the provision of energy to the community services, mainly in education, health and telecommunications.

Regarding the existing demands, $100 \%$ of Cambriú respondents and $87.71 \%$ stated that the energy provided by the system was sufficient. According to the survey carried out in the field, it was found that $93.75 \%$ of the residents had gas stoves, $81.25 \%$ radio, $37.5 \%$ televisions with parabolic receiver, $6.25 \%$ fans, $6.25 \%$ tank washing machine, $6.25 \%$ centrifuge and $18.75 \%$ cell phone charger. However, no family had an electric shower, and in four residences, two of them serving tourism, they used LPG (Liquefied Petroleum Gas) to heat the bath water (demand not considered in the LPT). It was verified, therefore, that all the demands defined in the LAP in use in the dwellings, were fulfilled by the system SIGIFI 30.

Figure 7 graphically illustrates the percentage of appliances used in communities. 


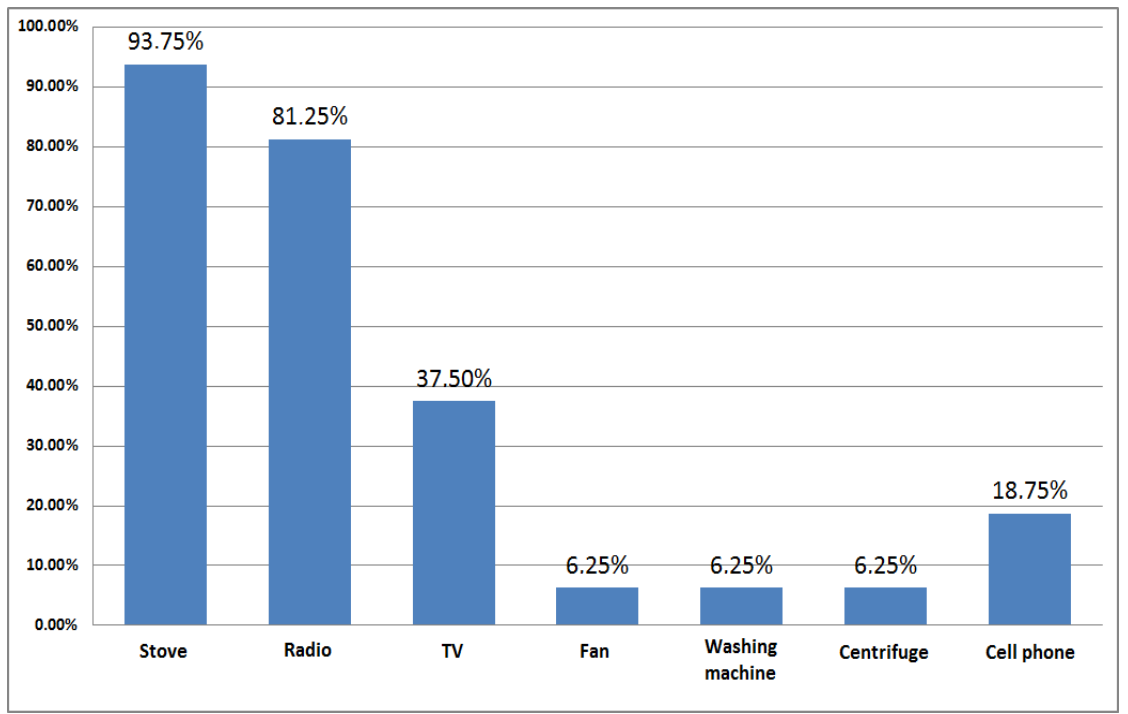

FIGURE 7. Types of appliances used in Cambriú and Foles isolated communities - PEIC-SP. Source: research database, 2014.

Previously to the photovoltaic electrification, the residents of the communities used other forms of obtaining energy such as candles, lamps, lampions and lanterns. After the electrification process, $33.33 \%$ of the population declared that they did not use other energy sources, and $66.67 \%$ still use candles and lamps, especially during periods of low sunshine due to climatic conditions.

The research also found that in addition to deficiencies in community services, there are still unmet needs, which are of great relevance to the communities. The families raised the question of the power provided by current systems that would be insufficient to maintain refrigerators, important for fish refrigeration to be marketed, and to conserve food for daily consumption.

Considering that modern refrigerators and freezers consume in the range of 20 to $90 \mathrm{~kW} / \mathrm{month}$, corresponding to powers of $200 \mathrm{~W}$ to $900 \mathrm{~W}$ according to the model, the current systems installed in the communities must be updated to a minimum of 50 $\mathrm{kWh} /$ month (SIGIFI 50) to power a refrigerator or up to $120 \mathrm{kWh} /$ month (SIGIFI 120) to hold a vertical freezer. Another refrigeration option proposed by Driemeier \& Zilles (2010) is the ice-making machines based on photovoltaic system without the use of batteries, which could be of community use.

Considering the factors exposed here with regard to the current effective demands for the communities surveyed, electrification can constitute an important structural factor for public policies that may be applied in these localities.

\section{Evaluation of the operating conditions of the installed systems}

According to the survey, it was found that in the units visited the facilities are of the same type, always following the SIGIFI 30 standard defined by the concessionaire, and there are still some old systems remaining from projects prior to the current electrification but which are used in isolation from the main system, therefore not considered in the analysis.
Concerning the interaction with the environment, the systems were installed in a way to cause a minimum of local interference, and the photovoltaic platforms are constituted by a set of protected and interconnected boxes as shown in the details of Figure 6, so that the wires which depart for the houses are all underground. An important aspect for photovoltaic energy, which is the positioning of the panels, which was considered during the installation so that the modules receive all-day lighting, free of shadows ensuring maximum system performance.

Another important aspect is that the batteries are protected from direct exposure to the sun and the effects of rain and sea air, guaranteeing a greater robustness and durability to the whole set.

The system is protected against overload, short circuit in the network and in the batteries, atmospheric electrical discharges on the panels and all the metallic platform is grounded avoiding risk of electric shock to the users of the system.

The quality of the electric energy generated is comparable to conventional grid $(110 \mathrm{~V}, 60 \mathrm{~Hz}$, sinusoid), although the maximum available power is limited by $500 \mathrm{~W}$ by the inverters, which limits the use. There is also a user alert function, regarding the excess consumption, performed by the load controller that generates "flashes" of power interruption signaling to users to decrease consumption.

The installation in all the houses visited was wellwired with switches and sockets in good condition.

Regarding the maintenance of the system, it was verified that the concessionaire assumed all responsibility, the users do not have access to the parts of the system, and a free telephone service (via 0800) is available for requesting maintenance.

This finding is very different from that reported by Serpa \& Zilles (2002), in previous projects where the lack of attention in these aspects, led to failures and decay of previous programs. 

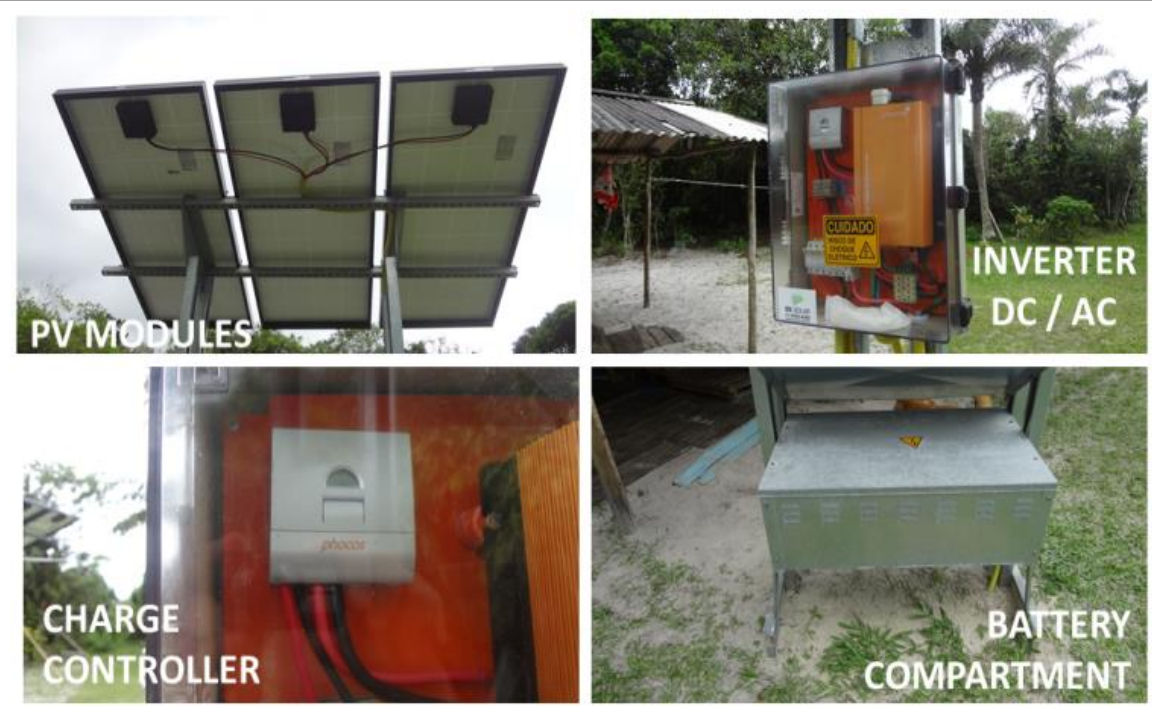

FIGURE 8. Photovoltaic installation details in Cambriú and Foles communities - PEIC-SP. Source: research database, 2014.

\section{CONCLUSIONS}

Based on the previous discussions, it can be concluded that the implementation was carried out in a conscious way, considering user capacity issues, technical assistance and maintenance, as well as adequate user fees can guarantee the sustainability of the system.

The SIGIFI 30-based systems individually meet the basic demands of isolated communities by considering the daily domestic needs of the residents, bringing various benefits such as quality of life, health and income generation. However, there are several unmet needs, such as the refrigeration and ice production required for fishing.

The projects prioritized meeting the individual demands of the residents to the detriment of community services such as schools, health posts, communications and cooperatives. The lack of this infrastructure contributes to the reduction of the settlement of the residents in the communities, with the displacement of the young population to the continent in search of opportunities.

It is concluded that the process of electrification in the communities surveyed will only achieve real success if it is linked to other public policy instruments that lead to a greater understanding of the diversities and peculiarities of traditional populations and the perception that the strong isolation leads to differentiated needs that if attended can conserve the populations in these areas preserving the cultures and traditions.

\section{ACKNOWLEDGMENTS}

The authors are grateful to the residents of Cambriú and Foles for the provision and help with the research, to the Forest Foundation for contributing with the documentation about PEIC-SP, to Elektro and Eletrobrás for information and data about the implementation, and finally to CAPES and MCT for the support.

\section{REFERENCES}

Campen van Bart, Guidi D, Best G (2000) Solar photovoltaics for sustainable agriculture and rural development. Roma, Food and Agriculture Organization of the United Nations.
Carvalho MCP de, Schmitt A (2012) Relatório TécnicoCientífico para identificação de famílias tradicionais presentes no Parque Estadual da Ilha do Cardoso. Fundação Florestal, São Paulo, 307 p.

Chandel SS, Naik MN, Chandel R (2015) Review of solar photovoltaic water pumping system technology for irrigation and community drinking water supplies. Renewable and Sustainable Energy Reviews 49:10841099. DOI: http://dx.doi.org/10.1016/j.rser.2015.04.083

Dell'Anna S, Menconi ME (2016) Off-grid approach to support the small scale food producers in rural areas. Agriculture and Agricultural Science Procedia 8:516-526. DOI: http://dx.doi.org/10.1016/j.aaspro.2016.02.061

Driemeier CE, Zilles R (2010) An ice machine adapted into an autonomous photovoltaic system without batteries using a variable-speed drive. Progress in Photovoltaics (Print) 18:299-305. DOI: http://dx.doi.org/10.1002/pip.960

EPE - Empresa de Pesquisa Energética. Anuário estatístico de energia elétrica 2016 - ano base de 2015, de Setembro de 2016. Available in: http://www.epe.gov.br. Accessed: Sep 27, 2017.

Gicquel R, Gicquel M (2013) Introduction to Global Energy Issues. London, CRC Press, $2^{\text {nd }}$ ed. 252 p.

Hassaniena R, Hassanien E, Lib M, Linb WD (2016) Advanced applications of solar energy in agricultural greenhouses. Renewable and Sustainable Energy Reviews 54(4):989-1001. DOI: http://dx.doi.org/10.1016/j.rser.2015.10.095

IEE-USP - Instituto de Eletrotécnica e Energia da Universidade de São Paulo (1994) Alternativas energéticas para Cananéia: uma experiência de planejamento energético local. São Paulo, Instituto de Eletrotécnica e Energia da Universidade de São Paulo, 54p.

Mendonça MA de F, Noda S do N, Noda H, Zilles R, Fedrizzi MC (2006) Energização rural comunitária: Experiências com sistemas fotovoltaicos. Avances en Energías Renovables y Medio Ambiente 10:12-39-12-46. 
Mishra P, Behera B (2016) Socio-economic and environmental implications of solar electrification: Experience of rural Odisha. Renewable and Sustainable Energy Reviews 56:953-964. DOI: http://dx.doi.org/10.1016/j.rser.2015.11.075

MME - Ministério de Minas e Energia (2015) Manual de Operacionalização do Programa Luz Para Todos - para o período de 2015 a 2018 (Decreto no 7.520, de 8/7/2011, alterado pelos Decretos no 8.387 , de $30 / 12 / 2014$ e no 8.493, de 15/7/2015). 29 p. Anexo à Portaria no 522, de 13 de novembro de 2015. Programa Nacional de Universalização do Acesso e Uso da Energia Elétrica Programa Luz para Todos. Eletrobras/MME.

MME - Ministério de Minas e Energia, ICMBio - Instituto Chico Mendes de Conservação da Biodiversidade (2016) Plano de Manejo - Área de proteção ambiental CananéiaIguape-Peruíbe, SP. MME/ICMBio.

Modi V, Mcdade S, Lallement D, Saghir J (2005) Energy services for the millennium development goals: achieving the millennium development goals. New York, The International Bank for Reconstruction and Development/The World Bank and the United Nations Development Programme.

Sánchez AS, Torres EA, Kalid R de A (2015) Renewable energy generation for the rural electrification of isolated communities in the Amazon Region. Renewable and Sustainable Energy Reviews 49:278-290. DOI: http://dx.doi.org/10.1016/j.rser.2015.04.075

São Paulo (Estado) Secretaria do Meio Ambiente (2001) Plano de manejo Fase 2. Parque Estadual da Ilha do Cardoso: projeto de preservação da mata atlântica. Secretaria do Meio Ambiente, 198 p.
Serpa PMN (2001) Eletrificação Fotovoltaica em comunidades caiçaras e seus impactos sócio culturais. Doutorado, Universidade de São Paulo, 252 p.

Serpa P, Zilles R (2002) Avaliação da difusão de sistemas fotovoltaicos domiciliares em comunidades tradicionais. São Paulo, Universidade de São Paulo, 10 p.

United Nations (2015) The Millennium Development Goals Report 2015. New York, United Nations.

Valer LR, Zilles R (2011) Potencial de uso de sistemas fotovoltaicos sin baterias en aplicaciones productivas rurales. Avances en Energías Renovables y Medio Ambiente 15:04.25-04.32.

Valer LR, Moraes AM de, Trigoso FM, Zilles R, Fedrizzi MC (2013) Experiências no semiárido cearense na implantação de sistemas fotovoltaicos para irrigação: lições aprendidas. Avances en Energías Renovables y Medio Ambiente 17:04.01-04.10.

Valer LR, Mocelin A, Zilles R, Moura E, Nascimento ACS do (2014) Assessment of socioeconomic impacts of access to electricity in Brazilian Amazon: case study in two communities in Mamirauá Reserve. Energy for Sustainable Development 20:58-65. DOI: http://dx.doi.org/10.1016/j.esd.2014.03.002

Williams NJ, Jaramillo P, Taneja J, Ustun TS (2015) Enabling private sector investment in microgrid-based rural electrification in developing countries: A review. Renewable and Sustainable Energy Reviews 52:12681281. DOI: http://dx.doi.org/10.1016/j.rser.2015.07.153

Zilles R, Trigoso FM, Fedrizzi MC (2000) Avaliação dos sistemas fotovoltaicos instalados nas residências dos moradores da Ilha do Cardoso. In: Encontro de Energia para Meio Rural, Campinas. AGRENER. NIPE-Unicamp. 